\title{
Gratitude to Referees 2011
}

DOI: $10.1134 / \mathrm{S} 0038094612010029$

The Editorial Board would like to express its sincere gratitude to the large group of referees of papers submitted for publication in Astronomicheskii Vestnik (Solar System Research). It is their selfless and dedicated service on which the successful work of the Editorial Board and the quality of published articles directly depend. The following referees assisted the journal in 2011:
V. A. Alekseev
V. A. Avdyushev
G. A. Bazilevskaya
E. A. Bonch-Osmolovskaya
T. V. Bordovitsyna
O. K. Cheremnykh
Yu. A. Chernetenko
N. V. Emel'yanov
E. N. Evlanov
I. V. Getselev
A. S. Ginsburg
I. V. Khatuntsev
K. V. Kholshevnikov

M. Yu. Khovrichev

B. P. Kondrat'ev

K. V. Kuimov

V. T. Masluk

L. I. Miroshnichenko

M. I. Mishchenko

V. N. Obridko

E. G. Osadchii

L. A. Pakhomov

M. N. Pavlinskii

E. L. Ruskol

G. O. Ryabova

L. V. Rykhlova

V. G. Sokolov

A. B. Struminskii

A. A. Ul'yanov

I. I. Volkov

D. M. Volobuyev

M. A. Zel'dovich

On behalf of the Editorial Board, Editor-in-Chief M.Ya. Marov 